\title{
TAAR1 induces a disturbed GSK3 $\beta$ phosphorylation in recurrent miscarriages through the ODC
}

\author{
Stavroula Stavrou' ${ }^{1}$, Michael Gratz ${ }^{1}$, Eileen Tremmel ${ }^{1}$, Christina Kuhn', Simone Hofmann ${ }^{1}$, Helene Heidegger ${ }^{1}$, \\ Mina Peryanova', Kerstin Hermelink', Stefan Hutter', Bettina Toth², Doris Mayr ${ }^{3}$, Sven Mahner ${ }^{1}$, Udo Jeschke ${ }^{1}$ \\ and Aurelia Vattai ${ }^{1}$
}

${ }^{1}$ Department of Gynecology and Obstetrics, Hospital of the LMU, Munich, Germany

${ }^{2}$ Department of Gynaecological Endocrinology and Reproductive Medicine, Medical University Innsbruck, Innsbruck, Austria

${ }^{3}$ Department of Pathology, Hospital of the LMU, Munich, Germany

Correspondence should be addressed to U Jeschke: udo.jeschke@med.uni-muenchen.de

\begin{abstract}
Objectives: Thyroid hormones play an important role in the maintenance of pregnancy. Their derivates, endogenous amines, act via binding to the trace amine-associated receptor (TAAR1). The aim of our study was to analyse the regulation of TAAR1, serine/threonine kinase (pGSK3 $\beta$ ) and ornithine decarboxylase (ODC) in placentas of healthy pregnancies, spontaneous (SM) and recurrent miscarriages (RM) and to investigate the influence of thyroid hormone derivates on TAAR1 expression in trophoblast model cells in vitro.

Methods: Patients with SM $(n=15)$ and RM $(n=15)$ were compared with patients with healthy pregnancies $(n=15)$ (pregnancy weeks 7-13 each). Immunohistochemistry was applied to analyse placental TAAR 1, PGSK3 $\beta$ and ODC expression. Protein expression of the receptors after stimulation with $\mathrm{T}_{3}, \mathrm{~T}_{1} \mathrm{AM}$ and $\mathrm{RO} 5203548$ in BeWo trophoblast model cells was determined via Western blot. Double-immunofluorescence was used to determine placental expression of TAAR 1 and ODC.

Results: Levels of TAAR1, pGSK3 $\beta$ and ODC were higher in placentas of RM in comparison to healthy controls. Stimulation of BeWo cells with $T_{3}, T_{1} A M$ and RO5203548 significantly increased TAAR1 expression. ODC expression in BeWo cells was upregulated through $\mathrm{T}_{3}$. Via double-immunofluorescence, TAAR1 and ODC-positive EVT could be detected.

Conclusions: Upregulation of placental TAAR1 may indicate an increased decarboxylation of thyroid hormones in miscarriages. Patients with RM may have a lack of $T_{3}$ through an enhanced transformation of $T_{3}$ into $T_{1} A M$ induced by the ODC. Future investigations could be carried out to analyse what role a prophylactic $T_{3}$ substitution plays for patients.
\end{abstract}

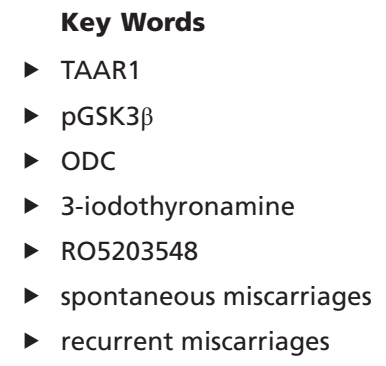

Endocrine Connections (2018) 7, 372-384

\section{Introduction}

Thyroid disorders such as hypothyroidism and hyperthyroidism are associated with increased miscarriage and stillbirth rates (1). Untreated hypothyroidism can result in a twofold increase of miscarriages; therefore, the maintenance of an euthyroid state is crucial for a healthy pregnancy (2). Thyroid hormones, which bind to the thyroid hormone receptor (THR), play an important role during trophoblast differentiation and the development of the foetal nervous system (3). THR belongs to the nuclear receptor superfamily, and it is involved in various http://www.endocrineconnections.org https://doi.org/10.1530/EC-17-0272 (c) 2018 The authors Published by Bioscientifica Ltd

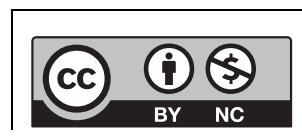

This work is licensed under a Creative Commons Attribution-NonCommercial 4.0 International License. 
physiological processes (4). In a former study, we were able to show that mRNA and protein expression of the THR isoforms THR $\alpha 1$, THR $\alpha 2$, THR $\beta 1$ and THR $\beta 2$ are reduced in spontaneous and recurrent miscarriages (RM) (5). The majority of THR seems to be expressed by decidual stromal cells (5).

Degradation of thyroid hormones results in the formation of trace amines (TAs), also referred to as thyronamines or endogenous amines (6). Transformation of thyroid hormones into TAs is conducted by the enzyme ornithine decarboxylase (ODC) through a deiodisation and a decarboxylation process (7). Thyronamines (3- $\mathrm{T}_{1} \mathrm{AM}$, $\mathrm{T}_{0} \mathrm{AM}$ ) are endogenous compounds, which can possibly be derived from L-thyroxine (T4) (7). Decarboxylated thyroid hormones act through rapid actions like rapid lowering of body temperature and heart rate, while classical thyroid hormones act epigenetically (8). Ornithine decarboxylase (ODC) is a rate-limiting enzyme for the biosynthesis of polyamines, and it is responsible for the decarboxylation of thyroid hormones $(9,10)$. Changes in the brain ODC/polyamine system can have an influence on the development of catecholaminergic nerve pathways (11). Bulgaroni and colleagues found that ODC upregulation may be linked to cytotrophoblast proliferation and placental repair in compensation to injuries induced by organophosphate pesticides (12).

Thyroid hormone derivates function by binding to the G-protein-coupled receptor trace amine-associated receptor 1 (TAAR1) (8). TAAR1 was first described in 2001 by Borowsky and coworkers (13). Upon activation of adenylcyclase, TAAR1 induces a rise of the intracellular cAMP level $(13,14)$. TAAR1 is expressed by the placenta, brain, spinal cord, stomach, pancreatic $\beta$-cells and immune cells like macrophages, leukocytes and dendritic cells (15, 16, 17). Different compounds, including dopaminergic, adrenergic and serotonergic classes and a wide spectrum of agonists, such as trace amines, common biogenic amines, amphetamine-like stimulants and 3-iodothyronamine can activate TAAR1 $(18,19,20)$. The only known TAAR1 antagonist to date is RO5212773 (EPPTB) (21).

TAAR1 has so far been investigated in the field of neuroscience whereby it could be shown that TAAR1 is able to modulate the serotonergic and dopaminergic system in the brain (15). As TAAR1 is a negative regulator of dopamine transmission, TAAR1 and its agonists as well as antagonists represent a target for psychiatric disorders like Parkinson's disease, depression and schizophrenia (15). Stimulation of TAAR1 can furthermore have a beneficial effect on glucose and obesity control in mice with type 2 diabetes mellitus (22).

$$
\text { http://www.endocrineconnections.org }
$$

In a recent study, we analysed the regulation of TAAR1 in breast cancer tissue of primary breast cancer patients and identified that TAAR1 seems to be an independent predictor for breast cancer survival (23). TAAR1 overexpression (IRS $\geq 6$ ) was associated with a significantly longer overall survival (OS) of breast cancer patients $(P=0.02)$ than reduced TAAR1 expression $(\mathrm{IRS}<6)$ during a maximum follow-up of 14 years, demonstrating that TAAR1 has a favourable effect on OS of early breast cancer patients (23).

It is speculated that TAAR1 directly or indirectly interferes with the $\beta$-arrestin2/Akt/GSK3 pathway $(24,25)$. GSK3 is a serine/threonine protein kinase, and it is encoded by the two genes GSK3A and GSK3B (26). Besides cellular proliferation, migration, glucose regulation and apoptosis, the isoform GSK3 $\beta$ is a key enzyme in the wnt-signalling pathways (27). Those are a group of signal transduction pathways that play an important role in carcinogenesis and embryo development. The latter is controlled through cell proliferation and cell migration, and wnt pathways regulate pre-implantation, blastocyst implantation and uterine decidualisation (27). Wnt-signalling proteins participate in numerous developmental events during embryogenesis and differentiation of diverse reproductive tissues $(28,29)$.

A crosstalk between TAAR1 and dopamine D2L receptor (D2R) has formerly been described $(6,30,31)$. Harmeier and colleagues found that the activation of the TAAR1-D2R complex negatively modulates GSK3 $\beta$ signalling in vitro and in vivo. D2R is a target receptor for various antipsychotic drugs, and TAAR1 can interact with D2R forming a functional heteromer $(6,32)$.

Aim of our study was to investigate the placental expression of TAAR1, GSK3 $\beta$ and ODC in healthy pregnancies and spontaneous as well as RM and to further analyse the crosstalk between these receptors. Additionally, the influence of TAAR1 ligands on the expression of TAAR1 in trophoblast model cells in vitro was assessed. As we assume that the processing of thyroid hormones through the ODC plays an important role during miscarriages, regulation of the ODC was a further component of the study.

\section{Materials and methods}

\section{Tissue samples}

Samples collected from spontaneous (SM, 15 cases) and RM, 15 cases) in the time period between 2011 and 2012 were obtained from the archives of the Gynaecology and Obstetrics Department of the Ludwig-Maximilians-

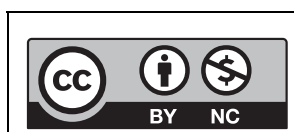

This work is licensed under a Creative Commons Attribution-NonCommercial 4.0 International License. 
University Munich, Germany. Samples from elective terminations of pregnancy (ETP, 15 cases) collected in the same time period were provided by outpatients clinic in Munich. Tissue samples were attained by curettage without any prior pharmacological induction. In cases of miscarriages, curettages were performed within $24 \mathrm{~h}$ after diagnosis. The average gestational age for ETP was $10.6 \pm 2.1$, for SM $10.1 \pm 1.5$ weeks and for RM $10 \pm 1.5$ weeks. Hypothyroidism as well as hyperthyroidism and TPO antibody positivity was excluded in all women. History taking was comprehensive, aiming to excludeapart from common disorders-potential involvement of clotting disorders and autoimmune diseases, which are already known as aggravating factors for increased risk for miscarriages. In all samples, analysis of chromosomal abnormalities was performed. In this study, PowerPlex 16HS multiple PCR system was used, which detects 16 STR loci, with the limitation of this method in picking up chromosomal abnormalities at base pair level. Analyses were carried out for all samples including controls. DNA extraction and profiling were performed as described by Ziegelmüller and coworkers (33). The PCR products were also analysed as described (33). Additionally, in all samples, microbiology analysis excluded possible intra-uterine infection. All women had a normal first trimester vaginal swab.

\section{Ethical approval and informed consent}

All procedures that involved human participants were in accordance with the ethical standards of the institutional and/or national research committee and with the Helsinki declaration of 1964 and its later amendments or comparable ethical standards. The study was approved by the Local Ethics Committee of the Ludwig-Maximilians University of Munich, Germany, and was assigned the reference number 33706. Consent has been obtained from each patient or subject after full explanation of the purpose and nature of all procedures used.

\section{Immunohistochemistry}

After tissue preparation, tissue samples were fixed in 3.7\% formalin and then embedded in paraffin. Formalin-fixed paraffin-embedded sections $(3 \mu \mathrm{m})$ were deparaffinised in Roticlear (Carl Roth, Karlsruhe, Germany), blocked and rehydrated with $3 \% \mathrm{H}_{2} \mathrm{O}_{2} /$ methanol for $20 \mathrm{~min}$. Rehydration of the slides was carried out by using an alcohol gradient up to distilled water. The slides were placed in a pressure cooker containing sodium citrate $(\mathrm{pH}=6.0)$. A blocking solution was used (Polymer Kit, Zytomed Systems, Berlin, Germany) to prevent any non-specific binding of the primary antibodies. Tissue sections were then incubated with the primary antibodies for $16 \mathrm{~h}$ at $4^{\circ} \mathrm{C}$ (Table 1). Reactivity was detected by using the ZytoChem Plus HRP Polymer System (Mouse/Rabbit) (Zytomed Systems; catalogue-ID: POLHRP-100), in accordance with the manufacturer's protocol. Staining was performed with DAB and counterstaining was performed with hemalaun. Appropriate positive controls (brain tissue for GSK3- $\beta$ and breast cancer tissue (23) and intestinal tissue for TAAR1 (34)) and negative controls (negative control serum added on third trimester placenta) (Negative Control for Super Sensitive Rabbit Antibodies, Rabbit IgG, BioGenex, Fremont, USA) were included in each experiment (Supplementary Fig. 1, see section on supplementary data given at the end of this article). Positive and negative control experiments of TAAR1 expression are shown in the Supplementary figure. Per slide, ten fields were examined by two independent observers with a Leitz Diaplan microscope (Leitz, Wetzlar, Germany) by applying the semi-quantitative immunoreactive score (IRS) (35). The IRS is calculated by multiplying the intensity of cell staining ( 0 : none; 1: weak; 2: moderate; 3 : strong) with the percentage of positively stained cells ( 0 : no staining; $1:<10 \%$ of the cells; 2: 11-50\%; 3: 51-80\%; 4: >80\%).

The pattern of the immunochemical staining reaction was evaluated by two independent blinded observers including a gynaecological pathologist (D M). In one

Table 1 Features of the antibodies used for staining.

\begin{tabular}{|c|c|c|c|}
\hline Antibody & Incubation & Blocking solution & $\begin{array}{l}\text { Blocking } \\
\text { condition }(\min )\end{array}$ \\
\hline $\begin{array}{l}\text { TAAR1, polyclonal (Rabbit lgG, } \\
\text { Abcam) }\end{array}$ & $1: 800$ in PBS $16 \mathrm{~h}$ at $4^{\circ} \mathrm{C}$ & $\begin{array}{l}\text { Reagent I (Polymer Kit, Zytomed } \\
\text { Systems, Berlin, Germany) }\end{array}$ & 15 \\
\hline $\begin{array}{l}\text { Phosphorylated GSK3 } \beta \text {, polyclonal } \\
\text { (phosphoY216) (Rabbit IgG, Abcam) }\end{array}$ & $1: 100$ in TBS $16 \mathrm{~h}$ at $4^{\circ} \mathrm{C}$ & $\begin{array}{l}\text { Reagent I (Polymer Kit, Zytomed } \\
\text { Systems, Berlin, Germany) }\end{array}$ & 5 \\
\hline $\begin{array}{l}\text { ODC, monoclonal (Mouse IgG, } \\
\text { Novus Biologicals) }\end{array}$ & $1: 4000$ in PBS $16 \mathrm{~h}$ at $4^{\circ} \mathrm{C}$ & $\begin{array}{l}\text { Reagent I (Polymer Kit, Zytomed } \\
\text { Systems, Berlin, Germany) }\end{array}$ & 5 \\
\hline
\end{tabular}

http://www.endocrineconnections.org

http://www.endocrineconnections.
https://doi.org/10.1530/EC-17-0272

(C) 2018 The authors Published by Bioscientifica Ltd

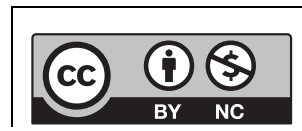

This work is licensed under a Creative Commons Attribution-NonCommercial 4.0 International License. 
case, the evaluation of the two observers of the GSK $\beta$ expression differed. This case was re-evaluated by both observers together. After the re-evaluation, both observers achieved the same result.

\section{Cell lines and cell stimulation}

The choriocarcinoma cell lines BeWo (ECACC, Salisbury, UK) and JEG-3 (ATCC), which are useful models of human trophoblasts, were used for the study. The cells were cultured in DMEM $\left(3.7 \mathrm{~g} / \mathrm{L} \mathrm{NaHCO}_{3}, 4.5 \mathrm{~g} / \mathrm{L}\right.$ D-glucose, $1.028 \mathrm{~g} / \mathrm{L}$ stable glutamine, and Na-Pyruvate; Biochrom, Berlin, Germany). 10\% heat-inactivated FCS was added to the medium, and the solution was incubated at an atmospheric $\mathrm{CO}_{2}$ concentration of $5 \%$ and at $37^{\circ} \mathrm{C}$.

BeWo and JEG-3 cells were separately grown on sterile 12 multiwell slides at a density of 500,000 cells $/ \mathrm{mL}$ DMEM with $10 \%$ foetal cow serum. After $4 \mathrm{~h}$, medium was changed to pure DMEM. The cells were stimulated with $0.01 \mathrm{nM}$ or $0.1 \mathrm{nM}$ triiodothyronine (T3) (Sigma T2877; Lot:106K1157V, Sigma-Aldrich), thyronamine $\left(\mathrm{T}_{0} \mathrm{AM}\right)$ (Fluka 80345, Lot: BCBL2185V, Buchs, Switzerland), 3-Iodothyronamine ( $\mathrm{T}_{1} \mathrm{AM}$ ) (Cayman Chemical) and RO5203548 (Glixx Laboratories, Hopkinton, MA, USA) for $2 \mathrm{~h}$ (PCR samples) and $48 \mathrm{~h}$ (Immunocytochemistry and Western blot samples), respectively. Control cells were incubated without stimulants. As a control solvent, the following buffers were used: The stimulant T3 has been diluted in $1 \mathrm{M} \mathrm{NaOH}$ in DMEM (Dulbecco's Modified Eagle Medium) and $\mathrm{T}_{1} \mathrm{AM}$ and RO5203548 were diluted in DMSO (Dimethylsulfoxide).

\section{Immunocytochemistry}

After incubation, the Quadriperm slides were fixated in an ethanol/methanol solution for $15 \mathrm{~min}$. Between each step, the slides were washed in PBS (Biochrom). Next, the primary antibody (anti-TAAR1) was applied for $16 \mathrm{~h}$ at $4^{\circ} \mathrm{C}$. Incubation with the secondary antibody (ZytoChem Plus HRP Polymer System (mouse/rabbit) Tytomed: Nr. POLHRP-100) for $30 \mathrm{~min}$ followed. Staining of the slides was carried out with 3-amino-9-ethylcarbazole plus (AEC plus; Dako) for 5-8 min, followed by counterstaining with hemalaun for 30 s and finally washing in tap water and cover-slipping of the slides.

Assessment of the slides was carried out with a Leitz Diaplan light microscope (Leitz) and a digital camera system (JVC, Yokohoma, Japan) by two independent observers. For each slide, six visual fields were examined

$$
\text { http://www.endocrineconnections.org }
$$

at a magnification of $\times 10$ and 25 . Per field, the cells were counted and assigned to three groups (negative, low, medium/strong staining).

\section{TaqMan-real-time PCR}

RNA of stimulated and control JEG-3 and BeWo cells was isolated using the NucleoSpinRNAII (Macherey-Nagel, Düren, Germany). Quantification and evaluation of RNA samples was carried out with the NanoPhotometer (Implen, Munich, Germany).

Reverse transcription was performed using the High-Capacity cDNA reverse transcription kit (Applied Biosystems) with a temperature protocol of $25^{\circ} \mathrm{C}$ for $10 \mathrm{~min}, 37^{\circ} \mathrm{C}$ for $2 \mathrm{~h}, 85^{\circ} \mathrm{C}$ for $5 \mathrm{~s}$ and hold at $4^{\circ} \mathrm{C}$.

The PCR was performed in 96-well reaction plates holding a volume of $20 \mu \mathrm{L}$. Each well contained $1 \mu \mathrm{L}$ TaqMan Gene Expression Assay 20× (Applied Biosystems), $10 \mu \mathrm{L}$ TaqMan Universal PCR Master Mix 2× (Applied Biosystems), $8 \mu \mathrm{L} \mathrm{H}_{2} \mathrm{O}$ (DEPC treated DI water, Sigma) and $1 \mu \mathrm{L}$ sample. For the PCR assay, ABI PRISM 7500 Fast (Applied Biosystems) was used with thermal cycling conditions of $20 \mathrm{~s}$ at $95^{\circ} \mathrm{C}, 40$ cycles of amplification with $3 \mathrm{~s}$ at $95^{\circ} \mathrm{C}$ and $30 \mathrm{~s}$ at $60^{\circ} \mathrm{C}$. For quantification of the expression, the $2^{-\Delta \Delta C T}$ method was used by applying $\beta$-actin as the housekeeping gene. Each experiment was validated three times.

\section{Western blot}

Stimulated and control cell samples were lysed for 30 min with $200 \mu \mathrm{L}$ buffer solution consisting of a 1:100 dilution of protease inhibitor (Sigma-Aldrich) in RIPA buffer (Radioimmunoprecipitation assay buffer, SigmaAldrich). The lysate was centrifuged and a Bradford protein assay of the supernatant followed. The proteins were separated according to their molecular weight by a SDS-PAGE and transferred onto a PVDF membrane (Merck Millipore). Non-specific binding was blocked via a 1-h incubation of the membrane with $1 \times$ Casein Solution (Vector Laboratories, Burlingame, CA, USA). The primary antibodies anti-TAAR1, anti-ODC and anti$\beta$-actin (Clone AC-15, Mouse IgG, Sigma), diluted in a 1:500 and 1:1000 Casein solution, respectively, were applied for $16 \mathrm{~h}$ at $4^{\circ} \mathrm{C}$. After rinsing with $1 \times$ Casein solution, the membrane was incubated with biotinylated anti-mouse IgG antibody, respectively anti-rabbit IgG antibody and $\mathrm{ABC}-\mathrm{AmP}$ reagent (both VECTASTAIN ABCAmP Kit for mouse IgG, Vector Laboratories) according to the manufacturer's protocol. Staining was performed 
with BCIP/NBT chromogenic substrate (Vectastain ABCAmP Kit, Vector Laboratories). Detection was carried out with Bio-Rad Universal Hood II (Bio-Rad Laboratories) and the values quantified using Bio-Rad Quantity One software (Bio-Rad Laboratories).

\section{Double-immunofluorescence}

To determine the cells that express TAAR1 and ODC in the decidua, double-immunofluorescence analysis with markers for extravillous trophoblast (EVT) and decidual stroma cells was performed. HLAG, which is a marker for EVT, was applied. Placental tissue of both ETP and RM groups were stained.

After tissue retrieval, tissue samples were fixed in $3.7 \%$ formalin and embedded in paraffin. Formalinfixed paraffin-embedded sections $(3 \mu \mathrm{m})$ were then deparaffinised in Roticlear (Carl Roth), rehydrated and blocked with $3 \% \mathrm{H}_{2} \mathrm{O}_{2} /$ methanol for $20 \mathrm{~min}$ for endogenous peroxidase activity. Rehydration of the slides was performed with an alcohol gradient up to distilled water. The slides were then placed in a pressure cooker containing sodium citrate $(\mathrm{pH}=6.0)$. To prevent any non-specific binding of the primary antibodies, a blocking solution was applied for $15 \mathrm{~min}$ (Ultra V-Block, Thermo Scientific, Lab Vision, Lot: PBQ140925). Afterwards, incubation was performed with the primary antibodies overnight at $4^{\circ} \mathrm{C}$ (Table 2). The secondary antibodies Cy-2-labelled goat-anti-rabbit IgG, diluted 1:100 (Dianova, Hamburg, Germany), Cy-3-labelled goat-anti-mouse IgG, diluted 1:500 (Dianova) and Cy-3labelled goat-anti-rabbit IgG, diluted 1:500 (Dianova) were applied on the slides. Finally, the slides were embedded in DAPI containing mounting buffer (Vector Laboratories, Vectashield H-1200). For the identification of TAAR1/HLAG expressing cells, the selected sections were additionally incubated with monoclonal HLAGFITC mouse IgG1 (Serotec, Bio-Rad) for $30 \mathrm{~min}$, which was diluted 1:50. Afterwards, the slides were analysed with the fluorescent Axioskop photomicroscope (Zeiss). Images were taken with a digital Axiocam camera system (Zeiss).

\section{Statistics}

Data collection, processing and analysis of statistical data were performed with IBM SPSS Statistics for Windows, version 22.0. IBM Corp. All statistical tests were two-sided with a 5\% significance level. Nonparametric Mann-Whitney $U$ tests were performed for comparison of central tendency. Wilcoxon signed-rank tests were performed for the statistical analysis of cell culture experiments. As causes for either spontaneous or RM differ, those two groups cannot be compared with each other. For ODC immunohistochemistry, a score developed from the percentage of low, middle and highly stained decidual cells in each sample was used. The formula is as follows: score $=\log 10(1 \times$ percentage of low stained cells $+10 \times$ percentage of middle intensity cells $+100 \times$ percentage of highly stained cells).

\section{Results}

\section{TAAR1 expression in the placenta}

Via immunohistochemical analysis, a significant upregulation of TAAR1 protein expression could be detected in syncytiotrophoblasts, cytotrophoblasts, decidua and glands of RM in comparison to healthy controls (all $P<0.001$ ) (Fig. 1). In spontaneous miscarriages, TAAR1 protein expression was also significantly increased in syncytiotrophoblasts, cytotrophoblasts, decidua and glands (decidua and glands: $P<0.001$; syncytiotrophoblasts: $P=0.002$ ) (Fig. 1).

\section{Phosphorylated GSK3 $\beta$ expression in the placenta}

Phosphorylated GSK3 $\beta$ protein (Y216) expression was significantly increased in RM in comparison to GSK3 $\beta$ protein expression in healthy controls in syncytiotrophoblasts $\quad(P=0.031), \quad$ cytotrophoblasts $(P=0.033)$ and in the decidua $(P<0.001)$. The difference between GSK3 $\beta$ expression in glands of RM compared to healthy controls was not significant $(P=0.286)$ (Fig. 2). There was no significant difference between GSK3 $\beta$ protein expression of spontaneous miscarriages and

Table 2 Features of the antibodies used for double-immunofluoresence.

\begin{tabular}{l} 
Primary antibodies \\
\hline TAAR 1 \\
TAAR 1 \\
ODC \\
HLAG
\end{tabular}

\begin{tabular}{l} 
Antibody type \\
\hline Mouse IgG monoclonal \\
Rabbit IgG polyclonal \\
Mouse IgG polyclocal \\
Mouse IgG1 monoklonal clone: MEM G/9
\end{tabular}

\section{Company}

Santa Cruz, sc-514311

Abcam, ab65633, Lot: GR171220-3

Novus Biologicals, SPM565, Lot: 4953-1XP160908

Serotec, MCA2044F, Lot: 300709

\begin{tabular}{c|}
\hline Dilution \\
\hline $1: 300$ \\
$1: 800$ \\
$1: 200$ \\
$1: 50$ \\
\hline
\end{tabular}

http://www.endocrineconnections.org

https://doi.org/10.1530/EC-17-0272
(C) 2018 The authors Published by Bioscientifica Ltd
This work is licensed under a Creative Commons Attribution-NonCommercial 4.0 International License. 
A

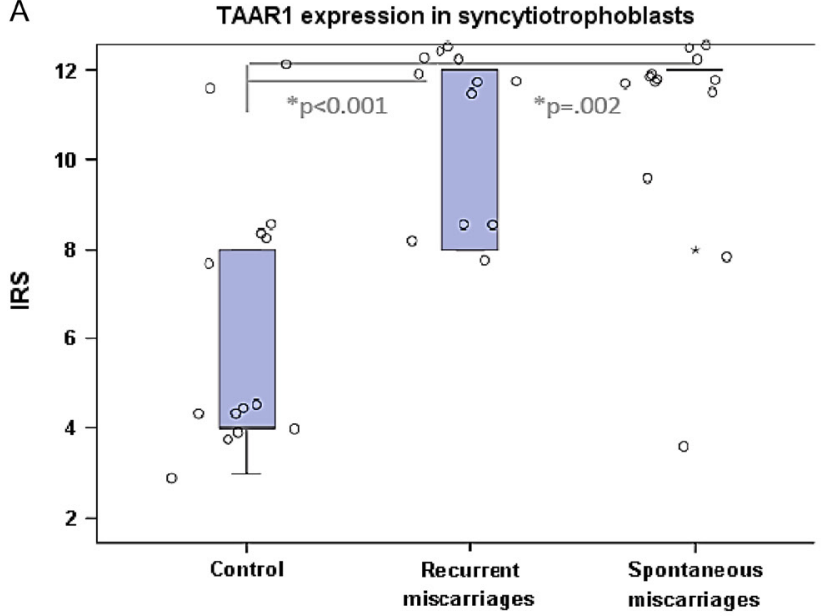

E

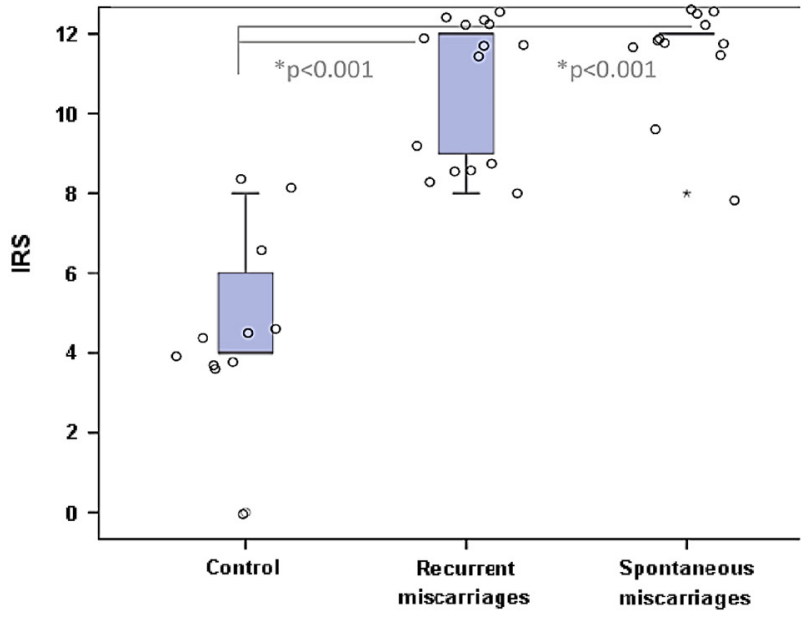

I

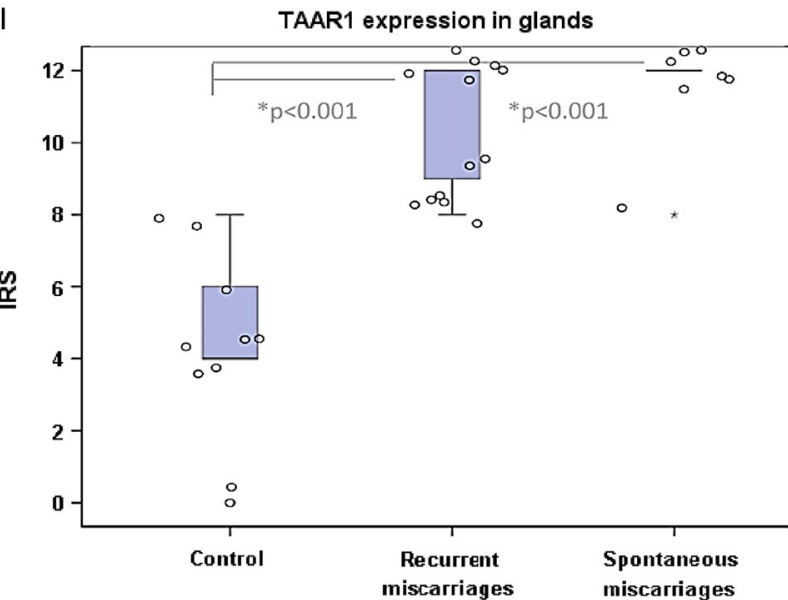

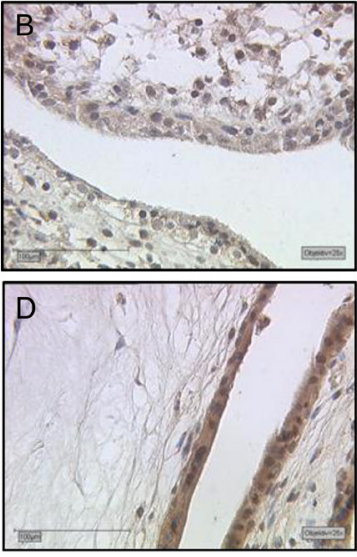
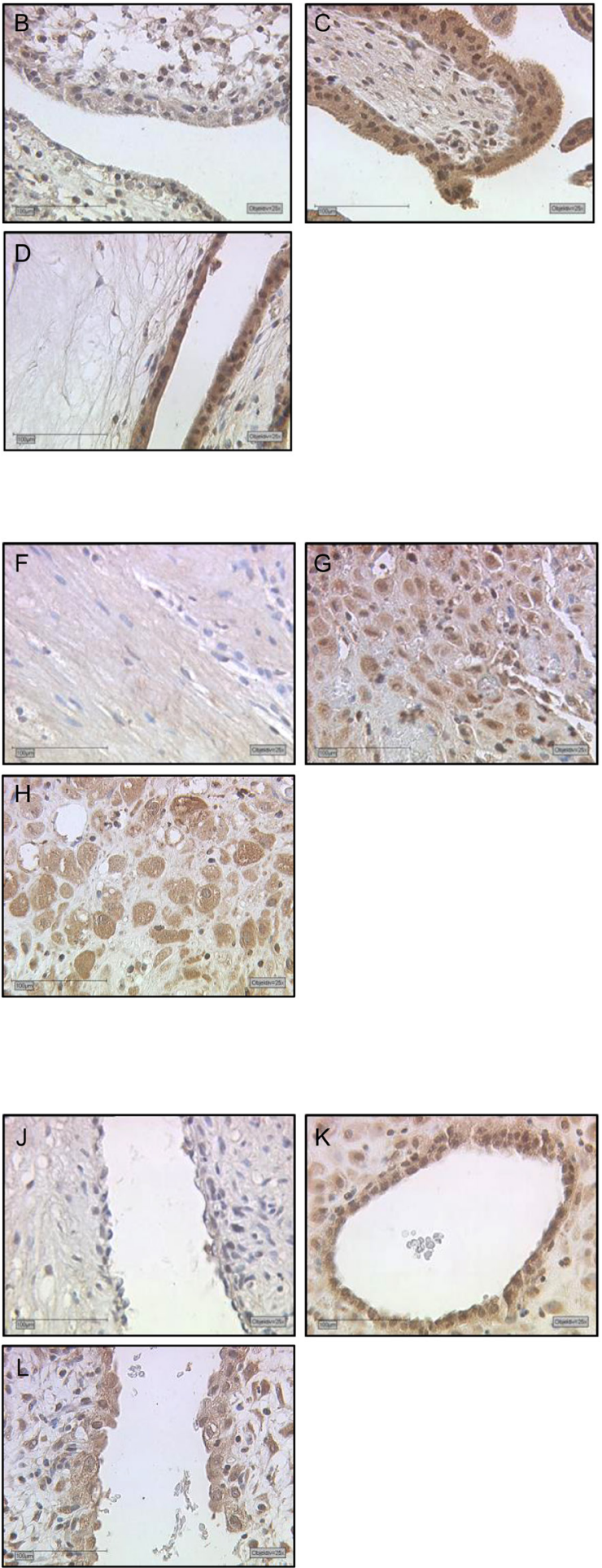

Figure 1

TAAR1 expression in control placental tissue, spontaneous miscarriages and recurrent miscarriages. (A) Boxplot and scatterplot (all jittered) of TAAR1 protein expression in syncytiotrophoblasts, (B) milder TAAR1 staining in syncytiotrophoblasts of control tissue, (C) stronger TAAR1 staining in syncytiotrophoblasts of recurrent miscarriages, (D) stronger TAAR1 staining in syncytiotrophoblasts of spontaneous miscarriages, (E) Boxplot and scatterplot of TAAR1 protein expression in decidua, (F) milder TAAR1 staining in decidua of control tissue, (G) stronger TAAR1 staining in decidua of RM, (H) stronger TAAR1 staining in decidua of SM, (I) Boxplot and scatterplot of TAAR1 protein expression in glands, (J) milder TAAR1 staining in glands of control tissue, (K) stronger TAAR1 staining in glands of RM, (L) stronger TAAR1 staining in glands of SM (all magnification $\times 25$ ).

$\begin{array}{lr}\text { http://www.endocrineconnections.org } & \text { ○ } 2018 \text { The authors } \\ \text { https://doi.org/10.1530/EC-17-0272 } & \text { Published by Bioscientifica Ltd }\end{array}$

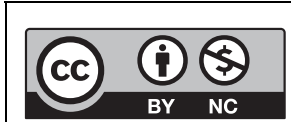

This work is licensed under a Creative Commons Attribution-NonCommercial 4.0 International License. 
A

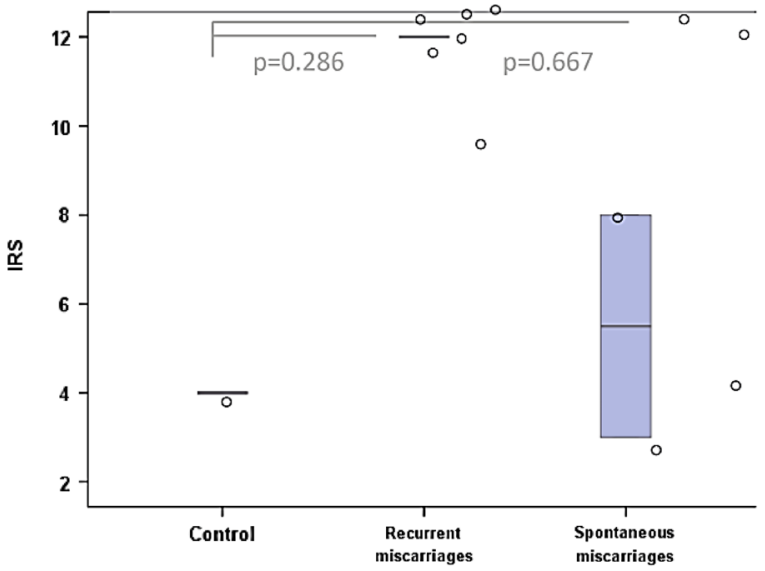

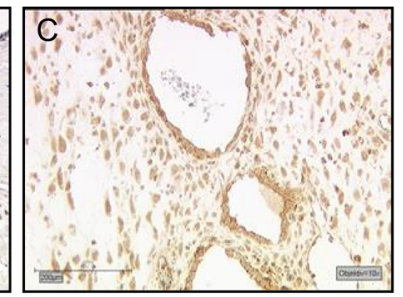

D
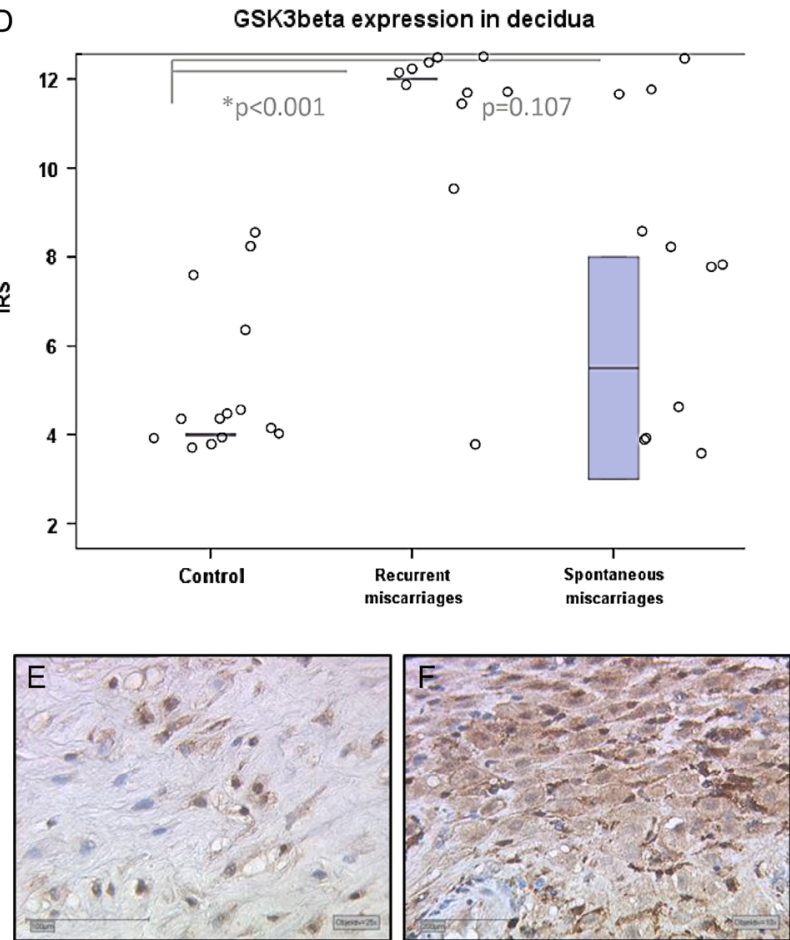

G

GSK3ß expression in cytotrophoblasts
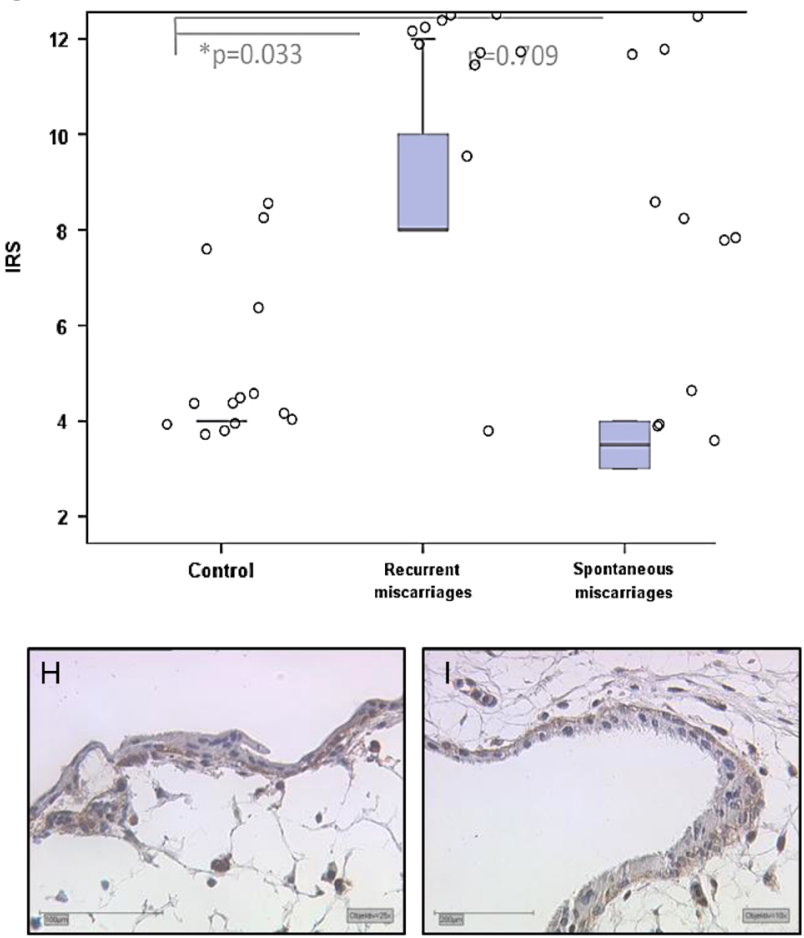

$\mathrm{J}$
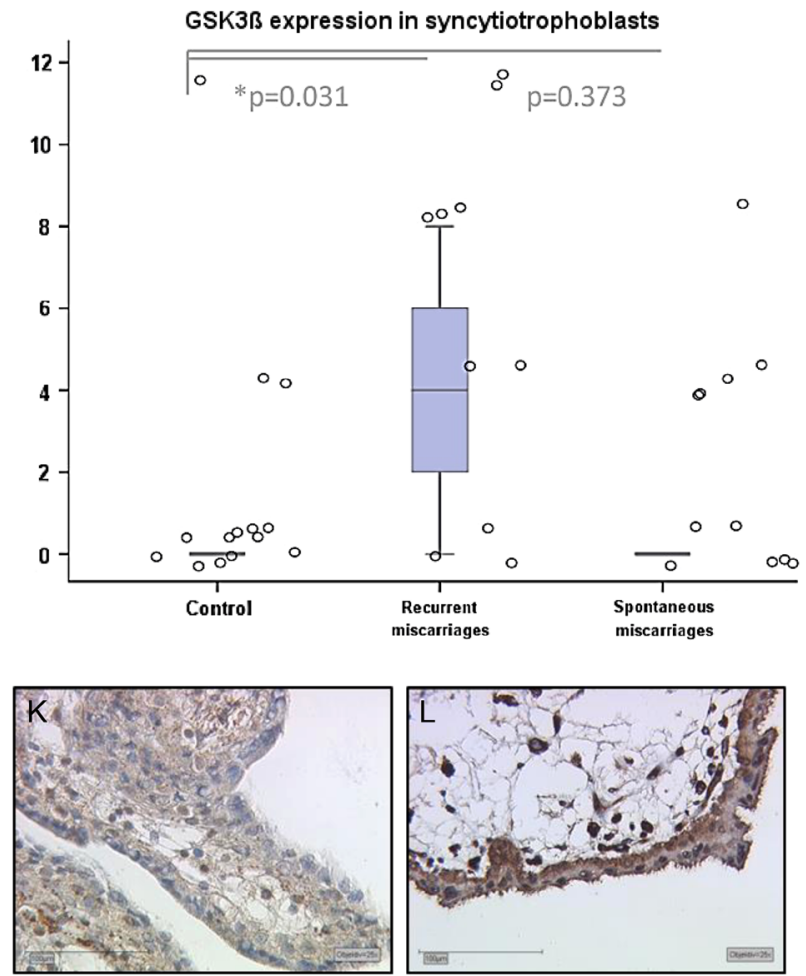

Figure 2

GSK3 $\beta$ expression in control placental tissue, spontaneous miscarriages and recurrent miscarriages. (A) Boxplot and scatterplot (all jittered) of GSK3 $\beta$ protein expression in glands, (B) GSK3 $\beta$ staining in glands of control tissue, (C) GSK3 $\beta$ staining in glands of SM, (D) Boxplot and scatterplot of GSK3 $\beta$ protein expression in decidua, (E) milder GSK3 $\beta$ staining in decidua of control tissue, $\times 25$ magnification, (F) stronger GSK3 $\beta$ staining in decidua of $\mathrm{RM}, \times 25,(\mathrm{G})$ Boxplot and scatterplot of GSK3 $\beta$ protein expression in cytotrophoblasts, (H) GSK3 $\beta$ staining in cytotrophoblasts of control tissue, $\times 10$, (I) GSK3 $\beta$ staining in cytotrophoblasts of RM, $\times 10$, (J) Boxplot and scatterplot of GSK3 $\beta$ protein expression in syncytiotrophoblasts, (K) milder GSK3 $\beta$ staining in syncytiotrophoblasts of control tissue, $\times 25$, (L) stronger GSK3 $\beta$ staining in syncytiotrophoblasts of RM, $\times 25$.

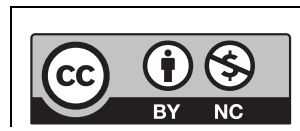

This work is licensed under a Creative Commons Attribution-NonCommercial 4.0 International License. 
ODC expression in different pregnancy weeks

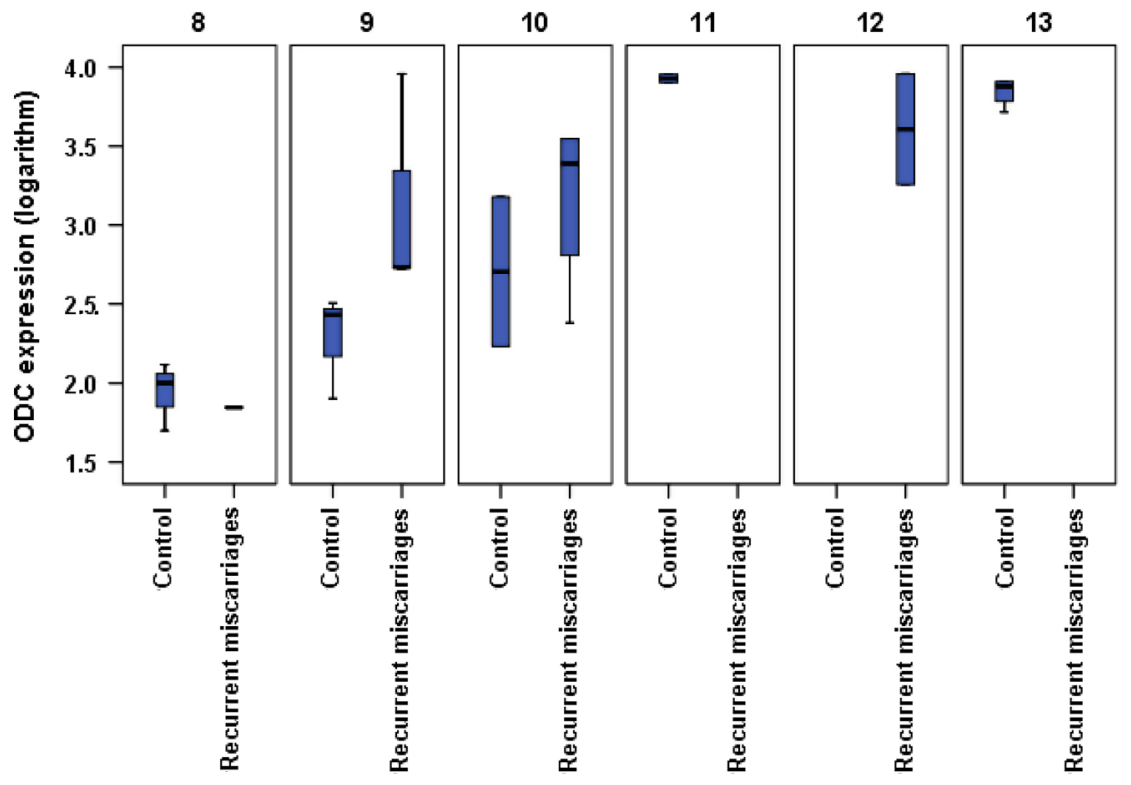

Figure 3

ODC expression in different pregnancy weeks. ODC expression has been analysed on the basis of a logarithmic scale with the following formula: $\log 10$ (intensity $1+10$ x intensity $2+100 \times$ intensity 3 ). ODC expression in decidua of recurrent miscarriages and control tissue increases with gestational age.

healthy controls in glands, decidua, syncytiotrophoblasts and cytotrophoblasts (Fig. 2).

\section{ODC expression in the placenta}

ODC expression in decidual tissue of controls and RM from 8 th up to 13 th week of gestation has been analysed and compared with each other (Fig. 3). In Fig. 3 it is apparent that ODC expression in decidual tissue of the controls and RM increases with gestational age (Fig. 4). There is a significant upregulation $(P=0.028)$ of ODC expression in $\mathrm{RM}$ in comparison to healthy controls for the subgroup of gestational weeks 8-10 (Fig. 4).

\section{A}

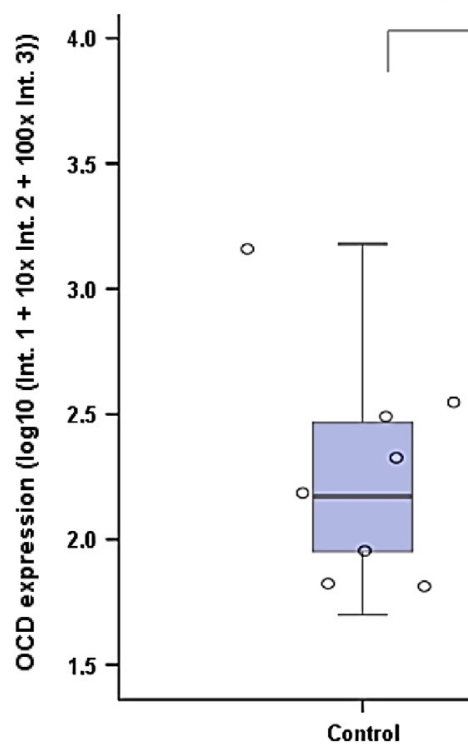

ODC expression in gestational pregnancy weeks 8-10
B.

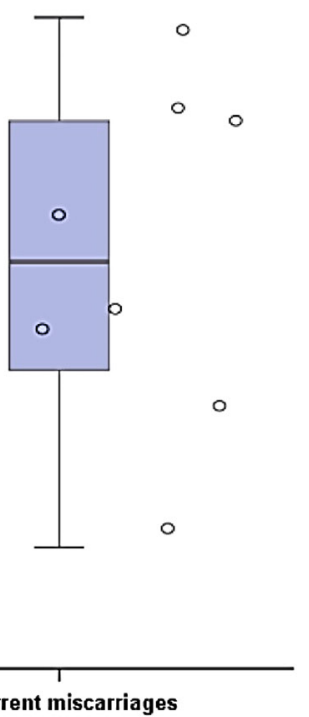

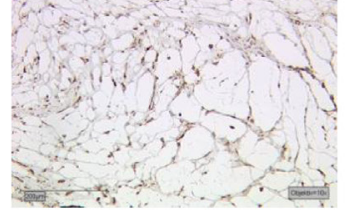
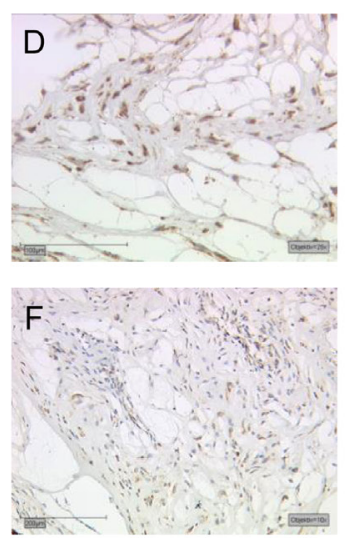

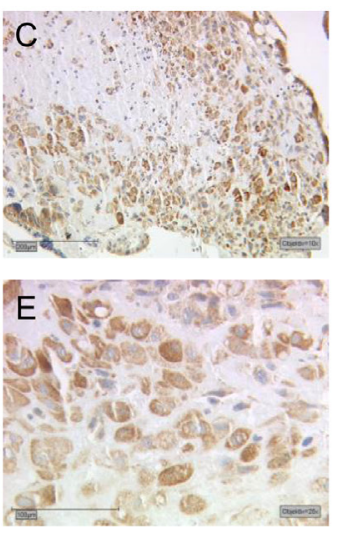

G

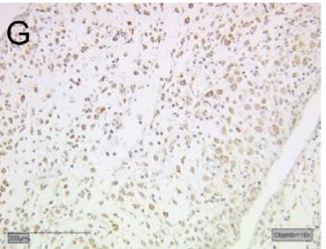

Figure 4

ODC protein expression in decidual tissue of placentas from pregnancy weeks 8 until 10. (A) Boxplot and scatterplot (jittered) of ODC protein expression in decidua of control (gestational weeks 8-10) and miscarriages (weeks 8-10), showing a significant upregulation of ODC expression in recurrent miscarriages $(P=0.028)$. ( $B, D)$ ODC staining in control decidua in the 9th gestational week, $\times 10(B)$ and $\times 25$ (D). (C, E) ODC staining in decidua of recurrent miscarriages in the 9th gestational week, $\times 10(C)$ and $\times 25(E)$. (F) ODC staining in control decidua in the 10 th gestational week, $\times 10$. (G) ODC staining in decidua of recurrent miscarriages in the 10th gestational week, $\times 10$.

$\begin{array}{lr}\text { http://www.endocrineconnections.org } & \text { ○ } 2018 \text { The authors } \\ \text { https://doi.org/10.1530/EC-17-0272 } & \text { Published by Bioscientifica Ltd }\end{array}$




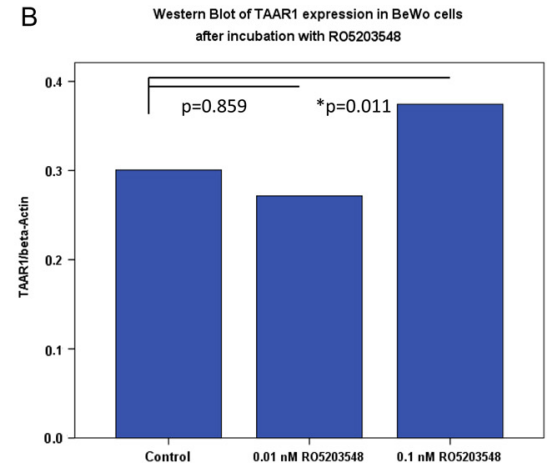

Control

Control

0.01 nM R05203548

.1 nM R05203548

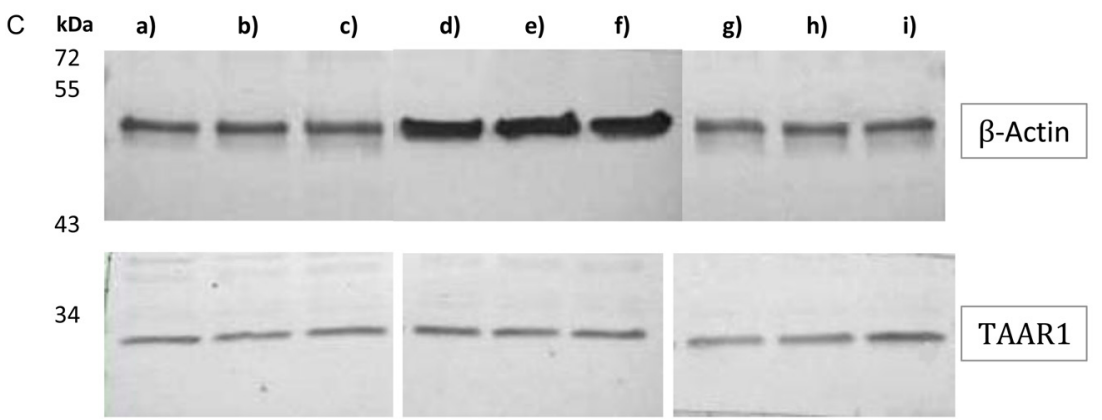

Figure 5

Western blot analysis of TAAR 1 expression after stimulation with $\mathrm{T}_{3}$ and RO5203548. (A) Bar graph diagram of TAAR1 expression after stimulation with $0.01 \mathrm{nM}$ and $0.1 \mathrm{nM}$ T3. (B) Bar graph diagram of TAAR1 expression after stimulation with $0.01 \mathrm{nM}$ and $0.1 \mathrm{nM}$ RO5203548. (C) Picture of Western blot membrane of BeWo cells where (D). BeWo cell control group. (E) BeWo cells stimulated with $0.01 \mathrm{nM}$ RO5203548, (F) BeWo cells stimulated with $0.1 \mathrm{nM}$ RO5203548. (G) BeWo cell control group, $(\mathrm{H})$ BeWo cells stimulated with $0.01 \mathrm{nM} \mathrm{T3,} \mathrm{(I)} \mathrm{BeWo} \mathrm{cells}$ stimulated with $0.1 \mathrm{nM}$ T3.
TAAR1 protein expression in BeWo trophoblast model cells after stimulation with $\mathrm{T}_{3}, \mathrm{~T}_{1} \mathrm{AM}$ and RO5203548

\section{Western blot}

The stimulant $T_{3}$ induced a significant upregulation of TAAR1 protein expression in BeWo cells at a concentration of $0.01 \mathrm{nM}(P=0.011)$ and $0.1 \mathrm{nM}(P=0.008)$ (Fig. 5). TAAR1 expression in BeWo cells was also upregulated after stimulation with $0.1 \mathrm{nM}$ RO5203548 $(P=0.011)$ for $6 \mathrm{~h}$ (Fig. 5). At a lower concentration, $0.01 \mathrm{nM}$, RO5203548 had no significant influence on TAAR1 expression $(P=0.859)$ (Fig. 5). The endogenous ligand $\mathrm{T}_{1} \mathrm{AM}$ induced a significant upregulation $(P=0.007)$ of TAAR1 expression

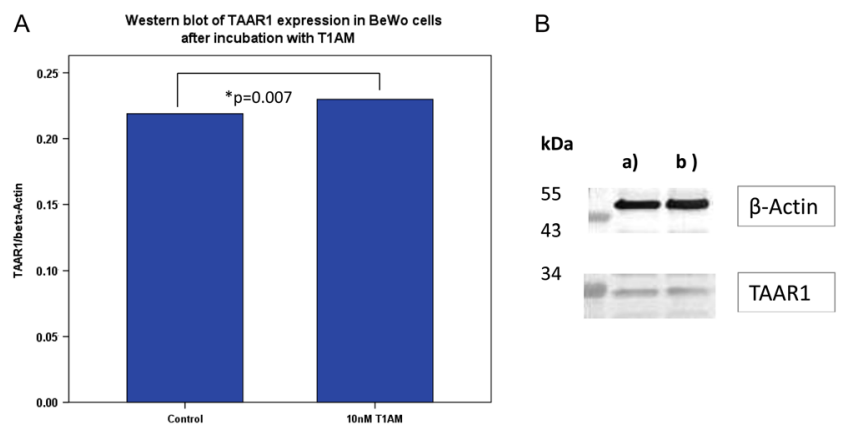

\section{Figure 6}

Western blot analysis of TAAR 1 expression after stimulation with $T_{1} A M$. (A) Bar graph diagram of TAAR1 expression after stimulation with $10 \mathrm{nM}$ $\mathrm{T}_{1} \mathrm{AM}$ showing a significant upregulation of TAAR1 expression $(P=0.007)$. (B) Picture of Western blot membrane of BeWo cells where (A). BeWo cell control group. (B) BeWo cells stimulated with $10 \mathrm{nM} \mathrm{T}_{1} \mathrm{AM}$.

http://www.endocrineconnections.org https://doi.org/10.1530/EC-17-0272

(C) 2018 The authors Published by Bioscientifica Ltd at a concentration of $10 \mathrm{nM}$ and after an incubation time of $6 \mathrm{~h}$ (Fig. 6).

ODC protein expression in BeWo trophoblast model cells after stimulation with $\mathrm{T}_{3}$

BeWo cells were stimulated with $0.01 \mathrm{nM}$ and $0.1 \mathrm{nM} \mathrm{T}_{3}$ for $48 \mathrm{~h}$ and ODC expression was analysed afterwards. Figure 7 shows a significantly increased ODC expression in BeWo cells after incubation with $0.01 \mathrm{nM} \mathrm{T}_{3}$ and $0.1 \mathrm{nM}$ $\mathrm{T}_{3}$ (both $P=0.007$ ) (Fig. 7).

\section{Double-immunofluorescence}

\section{TAAR1 and HLAG}

In placentas of electively terminated pregnancies (ETP) TAAR1-positive cells are stained in red (Fig. 8A) and HLAG-positive cells, which were identified as interstitial EVTs, are stained in green (Fig. 8B). Triple filter excitation of ETP shows the non-exclusive simultaneous expression of TAAR1 and HLAG in yellow (Fig. 8C), indicating that EVTs express TAAR1. ODC-positive cells are stained in red in control tissue (Fig. 8D), and an increased expression of ODC can be found in placentas of RM (Fig. 8G). Triple filter excitation of ETP shows a coexpression of ODC and HLAG visible in yellow (Fig. 8F). In placentas of RM, more cells stained in yellow can be detected compared to the controls, indicating an increased level of simultaneous expression of ODC and HLAG in RM (Fig. 8I).

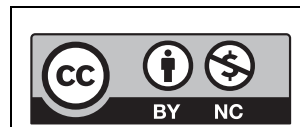

This work is licensed under a Creative Commons Attribution-NonCommercial 4.0 International License. 
A

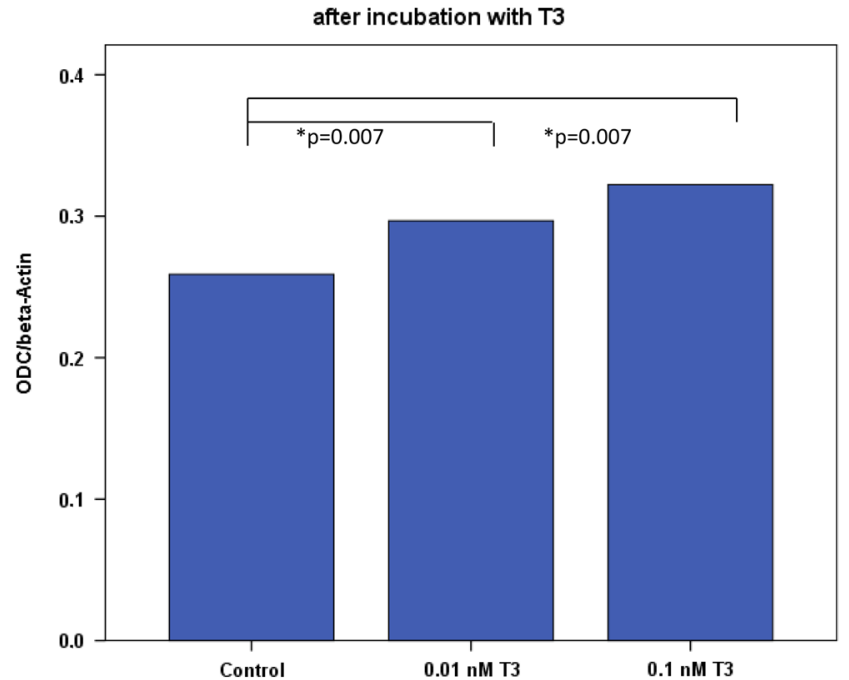

B

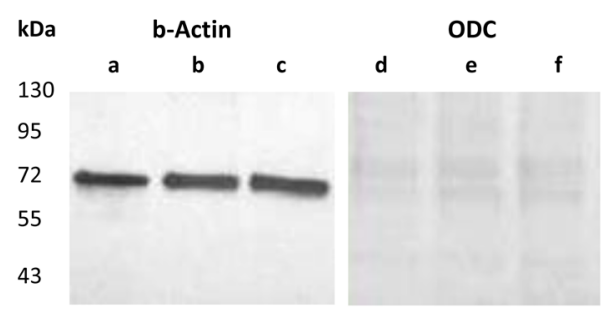

Figure 7

Western blot of ODC expression. (A) Boxplot analysis of ODC expression in BeWo cells after incubation with $\mathrm{T}_{3} .0 .01 \mathrm{nM}$ and $0.1 \mathrm{nM} \mathrm{T}_{3}$ induce a significant upregulation of ODC protein expression $(P=0.007)$. (B) Picture of Western blot membrane of BeWo cells where (A) and (B) BeWo cell control group. (B) and (E) BeWo cells stimulated with $0.01 \mathrm{nM} \mathrm{T3}$ for $24 \mathrm{~h}$. (C) and (F) BeWo cells stimulated with $0.1 \mathrm{nM}$ T3 for $24 \mathrm{~h}$.

\section{ODC and HLAG}

In control placental tissue of healthy pregnancies, an increased number of HLAG-positive cells, stained in green, can be detected (Fig. 8E), indicating an increased expression of EVT in controls in comparison to RM (Fig. 8H).

\section{Discussion}

In this study, the regulation of TAAR1, Phospho-GSK3 $\beta$ and ODC have been described in the placenta of healthy pregnancies and spontaneous as well as RM. A significant upregulation of TAAR1 in syncytio- and cytotrophoblasts, decidua and glands of spontaneous and RM may presumably be a sign for an increased decarboxylation of thyroid hormones in miscarriages. A lack of thyroid hormones during pregnancy may possibly induce an upregulation of TAAR1 expression, which denotes a metabolism of thyroid hormones. An excess of thyroid hormones may lead to an increase in decarboxylation

$$
\text { http://www.endocrineconnections.org }
$$

of thyroid hormones, which can consequently have a negative effect on the pregnancy.

An interaction between TAAR1 and D2R has recently been described (6). Harmeier and colleagues suggest that a heterodimerisation of TAAR1 and D2R elevates the recruitment of $\beta$ Arr2 to TAAR1 and activates Akt, which consequently leads to an inhibition of GSK3 $\beta$ via an alternative pathway (6). Enhanced GSK3 $\beta$ phosphorylation indicates a silencing of the downstream signalling cascade $(36,37)$. In our study, we discovered enhanced expression of phosphorylated GSK3 $\beta$ (pGSK3 $\beta$ ) expression in syncytiotrophoblasts, cytotrophoblasts and the decidua of RM in comparison to healthy controls and thereby a concomitant pGSK3 $\beta$ expression with TAAR1. An increase in pGSK3 $\beta$ expression leads to an inhibition of unphosphorylated GSK3 $\beta$ and consequently to an activation of the Wnt signalling. In a current study, we also investigated a reduced D2R expression in syncytiotrophoblasts and cytotrophoblasts of RM in comparison to trophoblasts of healthy controls (in revision at JCEM). These findings are in line with the results of Espinoza and coworkers, who detected a negative correlation between TAAR1 and D2R in the striatum of TAAR1-KO-mice, where D2 dopamine receptors are overexpressed and thereby selectively activate the G-protein-independent AKT/GSK3 signalling pathway (24). In contrast, Harmeier and coworkers found a concomitant increase of TAAR1 and D2R expression in the neurone cell line HEK293 (6). This difference might be due to the variability of TAAR1 and D2R expression in different cell lines and tissue.

One further aim of the study included the identification of ligands that have the ability to upregulate TAAR1 expression in trophoblast model cells and could thereby be responsible for the induction of miscarriages. Triiodothyronine, also known as $\mathrm{T}_{3}$, at a concentration of $0.01 \mathrm{nM}$ and $0.1 \mathrm{nM}$ induced a significant upregulation of TAAR1 expression in BeWo trophoblast model cells. The ligand RO5203548 significantly increased TAAR1 expression in BeWo and JEG-3 cells. RO5203548 has been described as a partial agonist and highly selective for TAAR1 in dopaminergic neurons (15). Partial agonists can either act as an agonist or an antagonist depending on the intrinsic activity of the receptor (15). Endogenous ligands, such as $\mathrm{T}_{1} \mathrm{AM}$, have a high affinity for TAAR1 $(13,18)$. In our study, $10 \mathrm{nM} \mathrm{T}_{1} \mathrm{AM}$ induced a significant upregulation of TAAR1 expression after an incubation time of $6 \mathrm{~h}$. We are aware of the fact that TAAR1 has an intron-less sequence. For that reason, we performed intense genomic DNA digestion to avoid that TAAR1 RNA is contaminated

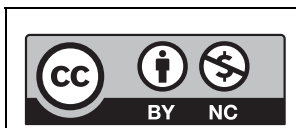

This work is licensed under a Creative Commons Attribution-NonCommercial 4.0 International License. 

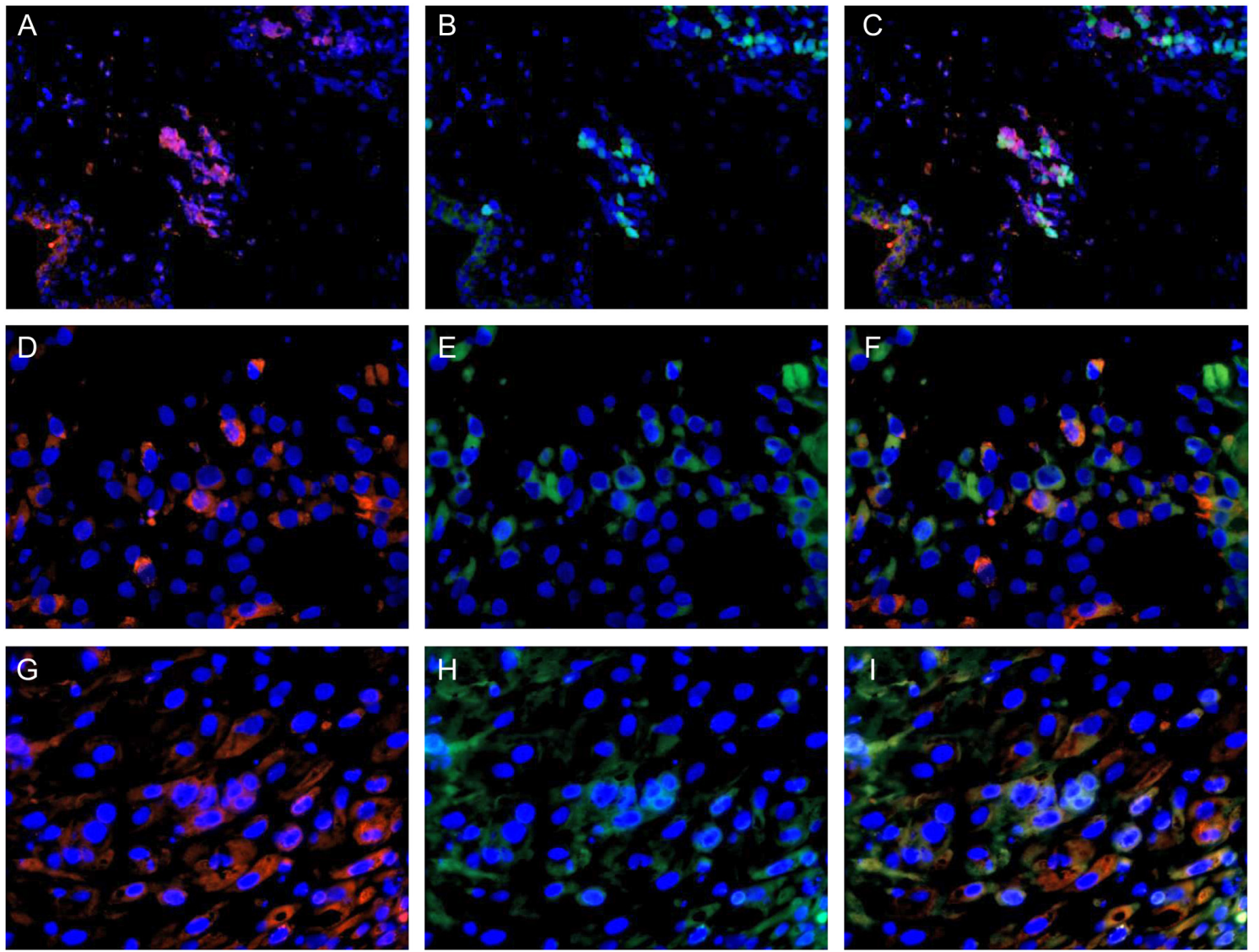

Figure 8

Double-immunofluorescence of TAAR1 and ODC. (A) Red stained TAAR1 expression in elective terminations of pregnancy. (B) Green stained HLAG expression in decidua of ETP placenta. (C) Coexpression of TAAR1 and HLAG in ETP visible in yellow. (D) Red stained ODC expression in decidua of ETP placenta. (E) Green stained HLAG expression in decidua of ETP placenta. (F) Double staining of both ODC and HLAG. A double expression is visible in yellow. (G) Red stained ODC expression in decidua of RM placenta. (H) Green stained HLAG expression in decidua of RM placenta. (I) Double staining of both ODC and HLAG. A double expression is visible in yellow; (all magnification $\times 40$ ).

with genomic DNA. We used commercially TAAR1 primers from 'Applied Biosystems by Thermo Fisher'. The policy of the company forbids to publish the primer sequences but the company guarantees the specificity of the sequences. An upregulation of TAAR1 is induced through the transformation of $\mathrm{T}_{3}$ into $\mathrm{T}_{1} \mathrm{AM}$. We could detect that $0.01 \mathrm{nM}$ and $0.1 \mathrm{nM} \mathrm{T_{3 }}$ induced a significant upregulation of ODC expression in BeWo cells via Western blot analysis. An increased expression of ODC after stimulation with $\mathrm{T}_{3}$ suggests that thyroid hormone derivates are present during miscarriages. Transformation of thyroid hormones into endogenous amines may therefore partly be carried out by the ODC. In our study, all patients with RM had normal thyroid hormone levels. Individuals with hypothyroidism and hyperthyroidism and patients with TPO antibody positivity were excluded from the study as those pathologies can influence miscarriage rates. We presume that patients with normal

$\begin{array}{lr}\text { http://www.endocrineconnections.org } & \text { () } 2018 \text { The authors } \\ \text { https://doi.org/10.1530/EC-17-0272 } & \text { Published by Bioscientifica Ltd }\end{array}$

thyroid hormonal levels possibly have a deficiency of T3 during pregnancy induced through the ODC. In a former study, we found that patients with spontaneous and RM have reduced expression of THR (5). A reduced level of THR during pregnancy may rather be due to an enhanced transformation of thyroid hormones into their derivate $\mathrm{T}_{1} \mathrm{AM}$ than to a decrease in thyroid hormone synthesis. One possible approach could therefore be a prophylactic substitution of L-thyroxin to patients with $\mathrm{RM}$, independent of their TSH and thyroid hormone levels. A further possibility to reduce the transformation of $\mathrm{T}_{3}$ into $\mathrm{T}_{1} \mathrm{AM}$ would be an inhibition of the ODC.

In conclusion, we found enhanced placental TAAR1 and pGSK3 $\beta$ expression in RM, which consequently leads to an inhibition of GSK3 $\beta$ and activation of the Wnt-signalling pathway. TAAR1 seems to be an inductor of the wnt-signalling pathway, and could play role in the embryonal development. Inhibition of GSK3 $\beta$, as

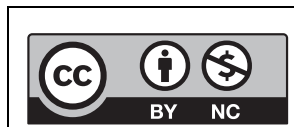

This work is licensed under a Creative Commons Attribution-NonCommercial 4.0 International License. 
observed in the neurological system through TAAR1, could also be detected in RM, indicating a TAAR1dependent regulation of GSK3 $\beta$ in RM. Using endogenous ligands, we demonstrated a $\mathrm{T}_{3}, \mathrm{RO} 203548$ and $\mathrm{T}_{1} \mathrm{AM}$ dependent upregulation of TAAR1 in trophoblast tumour cells. Aims of future studies include investigation of the functional interaction between TAAR1, ODC, GSK3 $\beta$ and the Wnt-signalling pathway in placentas of miscarriages. Future experiments should elucidate the role of $\beta$ Arr 2 in the signalling cascade in miscarriages. $\beta A$ Arr2 is known to dephosphorylate Akt and thereby activate GSK3 $\beta$ (6). In vivo experiments with a knockout or knockdown of TAAR1 through antisense or siRNA technologies should be considered. TAAR1 may represent a novel target for the treatment of miscarriages. Further studies are required to analyse the signalling pathways of the endogenous ligands of TAAR1 and to possibly re-examine thyroid hormone signalling (38).

\section{Supplementary data}

This is linked to the online version of the paper at https://doi.org/10.1530/ EC-17-0272.

\section{Declaration of interest}

The authors declare that we have no conflict of interest that could be perceived as prejudicing the impartiality of the research reported.

\section{Funding}

The study was funded by the Bayerische Gleichstellungsförderung (BGF) 2016, Germany.

\section{Author contribution statement}

A V, U J and S S conceived and designed the experiments. S S, M G, E T, C K and Si $\mathrm{H}$ performed the experiments. A V, U J, S S, M G, E T, C K, St H and $\mathrm{K}$ $\mathrm{H}$ analysed the data. A V, U J, S S, M G and K H wrote the research article. All authors read and approved the manuscript. S M, K H, H H, M P, S H, B T and $\mathrm{D} M$ did the final revision of the manuscript.

\section{Acknowledgements}

The authors thank Sandra Schulze for her excellent technical assistance.

\section{References}

1 Peleg D, Cada S, Peleg A \& Ben-Ami M. The relationship between maternal serum thyroid-stimulating immunoglobulin and fetal and neonatal thyrotoxicosis. Obstetrics and Gynecology 200299 1040-1043. (https://doi.org/10.1016/S0029-7844(02)01961-0)

2 Barber KJ, Franklyn JA, McCabe CJ, Khanim FL, Bulmer JN, Whitley GS \& Kilby MD. The in vitro effects of triiodothyronine on epidermal growth factor-induced trophoblast function. Journal of Clinical Endocrinology and Metabolism 200590 1655-1661. (https://doi.org/10.1210/jc.2004-0785)
3 Ohara N Tsujino T \& Maruo T. The role of thyroid hormone in trophoblast function, early pregnancy maintenance, and fetal neurodevelopment. Journal of Obstetrics and Gynaecology Canada 2004 26 982-990. (https://doi.org/10.1016/S1701-2163(16)30420-0)

4 Pestka A, Fitzgerald JS, Toth B, Markert UR \& Jeschke U. Nuclear hormone receptors and female reproduction. Current Molecular Medicine 201313 1066-1078. (https://doi.org/10.2174/156652401131 3070002)

5 Ziegelmuller B, Vattai A, Kost B, Kuhn C, Hofmann S, Bayer B, Toth B, Jeschke U \& Ditsch N. Expression of thyroid hormone receptors in villous trophoblasts and decidual tissue at protein and mRNA levels is downregulated in spontaneous and recurrent miscarriages. Journal of Histochemistry and Cytochemistry 201563 511-523. (https://doi.org/10.1369/0022155415582052)

6 Harmeier A, Obermueller S, Meyer CA, Revel FG, Buchy D, Chaboz S, Dernick G, Wettstein JG, Iglesias A, Rolink A, et al. Trace amine-associated receptor 1 activation silences GSK3beta signaling of TAAR1 and D2R heteromers. European Neuropsychopharmacology 201525 2049-2061. (https://doi. org/10.1016/j.euroneuro.2015.08.011)

7 Hoefig CS, Zucchi R \& Kohrle J. Thyronamines and derivatives: physiological relevance, pharmacological actions, and future research directions. Thyroid 201626 1656-1673. (https://doi.org/10.1089/ thy.2016.0178)

8 Brix K, Fuhrer D \& Biebermann H. Molecules important for thyroid hormone synthesis and action - known facts and future perspectives. Thyroid Research 20114 (Supplement 1) S9. (https://doi. org/10.1186/1756-6614-4-S1-S9)

9 Janne J, Poso H \& Raina A. Polyamines in rapid growth and cancer. Biochimica et Biophysica Acta 1978473 241-293.

10 Pegg AE. Recent advances in the biochemistry of polyamines in eukaryotes. Biochemical Journal 1986234 249-262. (https://doi. org/10.1042/bj2340249)

11 Slotkin TA \& Bartolome J. Role of ornithine decarboxylase and the polyamines in nervous system development: a review. Brain Research Bulletin 198617 307-320. (https://doi.org/10.1016/03619230(86)90236-4)

12 Bulgaroni V, Lombardo P, Rivero-Osimani V, Vera B, Dulgerian L, Cerbán F, Rivero V, Magnarelli G \& Guiñazú N. Environmental pesticide exposure modulates cytokines, arginase and ornithine decarboxylase expression in human placenta. Reproductive Toxicology 201339 23-32. (https://doi.org/10.1016/j.reprotox.2013.03.010)

13 Borowsky B, Adham N, Jones KA, Raddatz R, Artymyshyn R, Ogozalek KL, Durkin MM, Lakhlani PP, Bonini JA, Pathirana S, et al. Trace amines: identification of a family of mammalian $\mathrm{G}$ protein-coupled receptors. PNAS 200198 8966-8971. (https://doi. org/10.1073/pnas.151105198)

14 Barak LS, Salahpour A, Zhang X, Masri B, Sotnikova TD, Ramsey AJ, Violin JD, Lefkowitz RJ, Caron MG \& Gainetdinov RR. Pharmacological characterization of membrane-expressed human trace amine-associated receptor 1 (TAAR1) by a bioluminescence resonance energy transfer cAMP biosensor. Molecular Pharmacology 200874 585-594. (https://doi.org/10.1124/mol.108.048884)

15 Lam VM, Espinoza S, Gerasimov AS, Gainetdinov RR \& Salahpour A. In-vivo pharmacology of trace-amine associated receptor 1. European Journal of Pharmacology 2015763 136-142. (https://doi. org/10.1016/j.ejphar.2015.06.026)

16 Gozal EA, O’Neill BE, Sawchuk MA, Zhu H, Halder M, Chou CC \& Hochman S. Anatomical and functional evidence for trace amines as unique modulators of locomotor function in the mammalian spinal cord. Frontiers in Neural Circuits 20148 134. (https://doi.org/10.3389/ fncir.2014.00134)

17 Babusyte A, Kotthoff M, Fiedler J \& Krautwurst D. Biogenic amines activate blood leukocytes via trace amine-associated receptors TAAR1 and TAAR2. Journal of Leukocyte Biology 201393 387-394. (https://doi.org/10.1189/jlb.0912433)

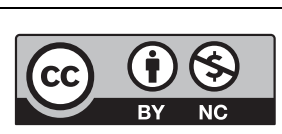

This work is licensed under a Creative Commons Attribution-NonCommercial 4.0 International License. 
18 Scanlan TS, Suchland KL, Hart ME, Chiellini G, Huang Y, Kruzich PJ, Frascarelli S, Crossley DA, Bunzow JR, Ronca-Testoni S, et al. 3-Iodothyronamine is an endogenous and rapid-acting derivative of thyroid hormone. Nature Medicine 200410 638-642. (https://doi.org/10.1038/nm1051)

19 Bunzow JR, Sonders MS, Arttamangkul S, Harrison LM, Zhang G, Quigley DI, Darland T, Suchland KL, Pasumamula S, Kennedy JL, et al. Amphetamine, 3,4-methylenedioxymethamphetamine, lysergic acid diethylamide, and metabolites of the catecholamine neurotransmitters are agonists of a rat trace amine receptor. Molecular Pharmacology 2001 60 1181-1188. (https://doi.org/10.1124/mol.60.6.1181)

20 Sotnikova TD, Caron MG \& Gainetdinov RR. Trace amine-associated receptors as emerging therapeutic targets. Molecular Pharmacology 200976 229-235. (https://doi.org/10.1124/mol.109.055970)

21 Bradaia A, Trube G, Stalder H, Norcross RD, Ozmen L, Wettstein JG, Pinard A, Buchy D, Gassmann M, Hoener MC, et al. The selective antagonist EPPTB reveals TAAR1-mediated regulatory mechanisms in dopaminergic neurons of the mesolimbic system. PNAS 2009 106 20081-20086. (https://doi.org/10.1073/pnas.0906522106)

22 Raab S, Wang H, Uhles S, Cole N, Alvarez-Sanchez R, Künnecke B, Ullmer C, Matile H, Bedoucha M, Norcross RD, et al. Incretin-like effects of small molecule trace amine-associated receptor 1 agonists. Molecular Metabolism 20165 47-56. (https://doi.org/10.1016/j. molmet.2015.09.015)

23 Vattai A, Akyol E, Kuhn C, Hofmann S, Heidegger H, von Koch F, Hermelink K, Wuerstlein R, Harbeck N, Mayr D, et al. Increased trace amine-associated receptor 1 (TAAR1) expression is associated with a positive survival rate in patients with breast cancer. Journal of Cancer Research and Clinical Oncology 2017143 1637-1647.

24 Espinoza S, Ghisi V, Emanuele M, Leo D, Sukhanov I, Sotnikova TD, Chieregatti E \& Gainetdinov RR. Postsynaptic D2 dopamine receptor supersensitivity in the striatum of mice lacking TAAR1. Neuropharmacology 201593 308-313. (https://doi.org/10.1016/j. neuropharm.2015.02.010

25 Revel FG, Meyer CA, Bradaia A, Jeanneau K, Calcagno E, André CB, Haenggi M, Miss MT, Galley G, Norcross RD, et al. Brain-specific overexpression of trace amine-associated receptor 1 alters monoaminergic neurotransmission and decreases sensitivity to amphetamine. Neuropsychopharmacology 201237 2580-2592. (https://doi.org/10.1038/npp.2012.109)

26 Grassilli E, Ianzano L, Bonomo S, Missaglia C, Cerrito MG, Giovannoni R, Masiero L \& Lavitrano M. GSK3A is redundant with GSK3B in modulating drug resistance and chemotherapy-induced necroptosis. PLoS ONE 20149 e100947. (https://doi.org/10.1371/ journal.pone.0100947)

27 Bao SH, Shuai W, Tong J, Wang L, Chen P \& Duan T. Increased Dickkopf-1 expression in patients with unexplained recurrent spontaneous miscarriage. Clinical and Experimental Immunology 2013 172 437-443. (https://doi.org/10.1111/cei.12066)

28 Logan CY \& Nusse R. The Wnt signaling pathway in development and disease. Annual Review of Cell and Developmental Biology 200420 781-810. (https://doi.org/10.1146/annurev. cellbio.20.010403.113126)

29 Sonderegger S, Pollheimer J \& Knofler M. Wnt signalling in implantation, decidualisation and placental differentiation review. Placenta 201031 839-847. (https://doi.org/10.1016/j. placenta.2010.07.011)

30 Espinoza S, Salahpour A, Masri B, Sotnikova TD, Messa M, Barak LS Caron MG \& Gainetdinov RR. Functional interaction between trace amine-associated receptor 1 and dopamine D2 receptor. Molecular Pharmacology 201180 416-425. (https://doi.org/10.1124/ mol.111.073304)

31 Leo D, Mus L, Espinoza S, Hoener MC, Sotnikova TD, Gainetdinov RR. Taar1-mediated modulation of presynaptic dopaminergic neurotransmission: role of D2 dopamine autoreceptors. Neuropharmacology 201481 283-291. (https://doi. org/10.1016/j.neuropharm.2014.02.007)

32 Strange PG. Antipsychotic drugs: importance of dopamine receptors for mechanisms of therapeutic actions and side effects. Pharmacological Reviews 200153 119-133.

33 Ziegelmüller B, Vattai A, Kost B, Kuhn C, Hofmann S, Bayer B, Toth B, Jeschke U \& Ditsch N. Expression of thyroid hormone receptors in villous trophoblasts and decidual tissue at protein and mRNA levels is downregulated in spontaneous and recurrent miscarriages. Journal of Histochemistry and Cytochemistry 201563 511-523.

34 Ito J, Ito M, Nambu H, Fujikawa T, Tanaka K, Iwaasa H \& Tokita S. Anatomical and histological profiling of orphan G-protein-coupled receptor expression in gastrointestinal tract of $\mathrm{C} 57 \mathrm{BL} / 6 \mathrm{~J}$ mice. Cell and Tissue Research 2009338 257-269. (https://doi.org/10.1007/ s00441-009-0859-x)

35 Remmele W \& Stegner HE. Recommendation for uniform definition of an immunoreactive score (IRS) for immunohistochemical estrogen receptor detection (ER-ICA) in breast cancer tissue. Pathologe 19878 138-140.

36 Beaulieu JM, Gainetdinov RR \& Caron MG. The Akt-GSK-3 signaling cascade in the actions of dopamine. Trends in Pharmacological Sciences 200728 166-172. (https://doi.org/10.1016/j.tips.2007.02.006)

37 Willi R. \& Schwab ME. Nogo and Nogo receptor: relevance to schizophrenia? Neurobiology of Disease 201354 150-157. (https://doi.org/10.1016/j.nbd.2013.01.011)

38 Grandy DK. Trace amine-associated receptor 1-family archetype or iconoclast? Pharmacology and Therapeutics 2007116 355-390. (https://doi.org/10.1016/j.pharmthera.2007.06.007)

Received in final form 8 December 2017 Accepted 30 January 2018 http://www.endocrineconnections.org https://doi.org/10.1530/EC-17-0272 (c) 2018 The authors Published by Bioscientifica Ltd

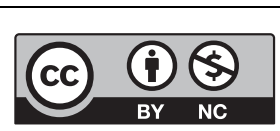

This work is licensed under a Creative Commons Attribution-NonCommercial 4.0 International License. 